\title{
The effect of trauma-focused therapy on the altered T cell distribution in individuals with PTSD: Evidence from a randomized controlled trial
}

\author{
Julia Morath ${ }^{\mathrm{a}, 1}$, Hannah Gola ${ }^{\mathrm{b}, 1}$, Annette Sommershof ${ }^{\mathrm{c}, 1}$, Gilava Hamuni ${ }^{\mathrm{b}}$, \\ Stephan Kolassa ${ }^{\mathrm{d}}$, Claudia Catani ${ }^{\mathrm{e}}$, Hannah Adenauer ${ }^{\mathrm{a}}$, Martina Ruf-Leuschner ${ }^{\mathrm{a}}$, \\ Maggie Schauer ${ }^{a}$, Thomas Elbert ${ }^{a}$, Marcus Groettrup ${ }^{\text {c,f }}$, Iris-Tatjana Kolassa ${ }^{\mathrm{a}, \mathrm{b}, *}$ \\ ${ }^{a}$ Center of Excellence for Psychotraumatology, Clinical Psychology and Neuropsychology, University of Konstanz, Germany \\ ${ }^{\mathrm{b}}$ Clinical and Biological Psychology, Institute of Psychology and Education, University of Ulm, Albert-Einstein-Allee 47, 89069 Ulm, Germany \\ ${ }^{\mathrm{c}}$ Division of Immunology, Department of Biology, University of Konstanz, 78457 Konstanz, Germany \\ 'SAP Switzerland AG, Tägerwilen, Switzerland \\ e Clinical Psychology and Psychotherapy, University of Bielefeld, Germany \\ ${ }^{\mathrm{f}}$ Biotechnology Institute Thurgau at the University of Konstanz, 8280 Kreuzlingen, Switzerland
}

\begin{abstract}
A B S T R A C T
Posttraumatic stress disorder (PTSD) is associated with a reduced ratio of naïve cytotoxic T lymphocytes, an increased ratio of memory cytotoxic T lymphocytes, and a reduced proportion of FoxP3 ${ }^{+}$regulatory $\mathrm{T}$ lymphocytes. This study investigated whether these immunological alterations are reversible through an evidence based psychotherapeutic treatment. Therefore, 34 individuals with PTSD were randomly assigned to either a treatment condition of 12 sessions narrative exposure therapy (NET) or a waitlist control (WLC) group. PTSD symptoms were significantly reduced in the NET group, but not in the WLC group, four months post therapy (effect size: Hedges' $g=1.61$ ). One year after therapy, PTSD symptoms were improved even further in the NET group compared to baseline (Hedges' $g=1.96$ ). This symptom improvement was mirrored in an increase in the originally reduced proportion of regulatory T cells $\left(\mathrm{T}_{\mathrm{regs}}\right)$ in the NET group at the one year follow up, when comparing subgroups matched for baseline $T_{\text {reg }}$ numbers. However, no changes were found for the initially reduced proportion of CD45RA ${ }^{+} C C R 7^{+}$naïve $\mathrm{T}$ lymphocytes. In conclusion, NET was effective in reducing trauma related PTSD symptoms and had a positive effect on the proportion of $\mathrm{T}_{\text {regs }}$ cells, thus demonstrating an effect of psychotherapy on an immunological level. Yet, the shift in the proportion of naïve and memory $T$ lymphocytes in individuals with PTSD, discussed in the literature as a correlate of premature immunosenescence, was not reversible and thus might render these patients permanently more susceptible to infectious diseases.
\end{abstract}

\section{Introduction}

The probability of developing posttraumatic stress disorder (PTSD) after psychological trauma increases with the number of traumatic event types experienced (Neuner et al., 2004a; Kolassa et al., 2010). Likewise, a dose-response effect of trauma exposure during childhood has been demonstrated for the development of

\footnotetext{
* Corresponding author. University of Ulm, Institute of Psychology and Education, Clinical and Biological Psychology, Albert-Einstein-Allee 47, 89069 Ulm, Germany. Tel.: +49 (0)731 5026590; fax: +49 (0)731 5026599.

E-mail address: Iris.Kolassa@uni-ulm.de (I.-T. Kolassa).

1 Equally contributing.
}

physical health problems (Felitti et al., 1998) and impaired brain development (Teicher et al., 2012). Furthermore, an increased risk for somatic diseases like chronic pain, cancer, cardiovascular, res piratory, gastrointestinal, and autoimmune diseases has been re ported for individuals with PTSD (Boscarino, 2004; Boscarino et al., 2010; Sareen et al., 2007), where the poor physical health found in individuals with PTSD might be moderated by altered immune functions and inflammatory processes (Von Känel et al., 2007; Pace and Heim, 2011; Spitzer et al., 2010).

However, linking PTSD to alterations of bulk T cell populations, representing a major branch of adaptive immunity, has been controversial: Whereas the number of circulating $\mathrm{CD}^{+}$cytotoxic $\mathrm{T}$ cells in individuals with PTSD has been found to be mostly lower (Ironson et al., 1997; Kawamura et al., 2001; Sommershof et al., 
2009) or unchanged (Altemus et al., 2006; Laudenslager et al., 1998; Vidović et al., 2007; Wilson et al., 1999), the number of circulating $\mathrm{CD}^{+} \mathrm{T}$ lymphocytes or $\mathrm{CD} 4^{+} \mathrm{T}$ helper cells has been found to be lower, unchanged or even higher (Ironson et al., 1997; Laudenslager et al., 1998; Boscarino and Chang, 1999; Wilson et al., 1999; Kawamura et al., 2001; Boscarino, 2004; Vidović et al., 2007; Sommershof et al., 2009). As peripheral T lymphocytes consist of a range of functionally different subpopulations, one reason for these inconsistent findings might be that changes in PTSD might be specific to certain $\mathrm{T}$ lymphocyte activation and differentiation states. Sommershof et al. (2009) investigated this further differ entiation of $\mathrm{CD}^{+} \mathrm{T}$ helper and $\mathrm{CD}^{+}$cytotoxic $\mathrm{T}$ cells in naïve, memory and effector cells, applying a differentiation model of $\mathrm{T}$ cells defined by changes in the expression of the lineage markers CD45RA and CCR7 (Hamann et al., 1999; Sallusto et al., 1999). They found a decreased ratio of $\left(\mathrm{CD} 45 \mathrm{RA}^{+} \mathrm{CCR}^{+}\right)$naïve $\mathrm{CD} 8^{+} \mathrm{T}$ cells and an increased proportion of $\left(\mathrm{CD} 4 \mathrm{RA}^{-}\right)$memory $\mathrm{CD} 8^{+} \mathrm{T}$ cells in in dividuals with PTSD (Sommershof et al., 2009). As a shrinking repertoire of naïve $\mathrm{T}$ cells may correlate with an enhanced sus ceptibility to infectious diseases (Fagnoni et al., 2000; Shen et al., 1999), this reduction in naïve T cells represents a possible expla nation for the enhanced risk of infectious diseases in individuals with PTSD (Sommershof et al., 2009). Furthermore, Sommershof et al. (2009) observed a 50\% decrease in the proportion of $\mathrm{CD}^{+}{ }^{+} \mathrm{CD} 25^{+} \mathrm{FoxP}^{+}$regulatory $\mathrm{T}$ cells $\left(\mathrm{T}_{\mathrm{reg}}\right)$ in individuals with PTSD. $T_{\text {reg }}$ cells are critical for maintaining balance in the immune system, regulating the immune response, and preventing autoim mune diseases (Vignali et al., 2008). Decreased counts of $\mathrm{CD}^{+}{ }^{+} \mathrm{CD} 25^{+} \mathrm{FOXP}^{+} \mathrm{T}_{\text {reg }}$ cells have been associated with autoim mune diseases like diabetes, multiple sclerosis, rheumatoid arthritis, psoriasis, anemia and eczema (Bennett et al., 2001; Buckner, 2010; Wildin et al., 2002), conditions for which in dividuals with PTSD show an increased risk (Boscarino, 2004; Boscarino et al., 2010; Weisberg et al., 2002).

Given the considerable prevalence of traumatic stress, and in particular the high prevalence of PTSD in populations affected by conflict, terror and combat (Neuner et al., 2004a; Neuner and Elbert, 2007), a highly relevant question in the context of trau matic stress and physical disease is: Can effective treatment reverse the effects of traumatic stress not only on a psychological but also on an immunological level?

Trauma focused psychotherapeutic interventions may effec tively reduce trauma related mental suffering in individuals with PTSD (Ehlers et al., 2010; Cloitre, 2009; Kleim et al., 2012; Seidler and Wagner, 2006), and, in individuals with PTSD with comorbid borderline personality disorder (Bohus et al., 2013) or comorbid substance abuse (van Dam et al., 2013). Moreover, it was demon strated that successful psychotherapeutic treatment also signifi cantly reduced cough, diarrhea, and fever (Neuner et al., 2008).

Yet, to our knowledge no study investigated the effect of psy chotherapy on T lymphocyte distribution in individuals with PTSD. So far, the impact of psychological interventions on $\mathrm{T}$ lymphocyte populations has mainly been examined in patients with cancer and human immunodeficiency virus (HIV), yielding mixed results. There are studies reporting a stabilization of $\mathrm{CD} 4^{+} \mathrm{T}$ lymphocytes after psychotherapeutic interventions (Creswell et al., 2009; Petrie et al., 2004; Sherman et al., 2000); however, $\mathrm{CD}^{+}$and $\mathrm{CD}^{+} \mathrm{T}$ lymphocytes were not affected in other studies (Antoni et al., 2006; Carrico et al., 2005; Hosaka et al., 2000).

Furthermore, we know that effective psychotherapy with Narrative Exposure Therapy (NET) can reverse the increased level of DNA strand breaks observed in individuals with PTSD compared to controls (Morath et al., in press). NET is a trauma focused treatment approach for PTSD, developed for survivors of war and torture (Schauer et al., 2011a). Its efficacy has been proven in a number of randomized controlled trials in post conflict regions (Ertl et al., 2011; Neuner et al., 2004b) and in Europe (Hensel Dittmann et al., 2011; Robjant and Fazel, 2010).

The present study has two aims: 1) to extend the findings by Sommershof et al. (2009) in a larger sample of individuals with PTSD, trauma exposed non PTSD subjects and non exposed con trols and 2) to investigate whether the altered $\mathrm{T}$ cell distribution in individuals with PTSD can be reversed by psychotherapeutic treatment with NET. Individuals with PTSD were investigated before treatment and four and 12 months after the end of therapy and $\mathrm{T}$ cell differentiation subsets were analyzed. We hypothesized that the NET treatment group would show an increase in the pro portions of $\mathrm{CD} 45 \mathrm{RA}^{+} \mathrm{CCR} 7^{+}$naïve $\mathrm{CD} 8^{+}$as well as in the proportion of $\mathrm{CD}^{+} \mathrm{CD}^{2} 5^{+} \mathrm{FOXP3}^{+} \mathrm{T}_{\text {reg }}$ cells.

\section{Methods}

\subsection{Participants}

Thirty four individuals with PTSD and 43 non PTSD controls were recruited through the Center of Excellence for Psycho traumatology, University of Konstanz, and public advertisements. Sixteen subjects with PTSD and 27 controls were also participants in a previous study by Sommershof et al. (2009). After the initial screening, individuals with PTSD (age 16-47 years) - refugees (13 Africa, 21 Middle East) with a history of war and torture experi ences - were randomly assigned to either a treatment (NET group: $n \quad 17$ ) or a waitlist control condition (WLC group: $n$ 17). The non PTSD control group (age 16-50 years) consisted of refugees and immigrants (9 Africa, 13 Balkan, 21 Middle East) without PTSD and varying traumatic load (0-9 traumatic event types). As the number of traumatic events experienced influences T cell distri bution in a cumulative way (Sommershof et al., 2009), we further divided the control group into a group with substantial trauma exposure (trauma exposed, $n$ 24) and a control group with no or little trauma exposure (non trauma exposed, $n$ 19) by median split of a traumatic load index. ${ }^{2}$

Exclusion criteria were acute infections or chronic somatic ill nesses (e.g., HIV, osteoarthrosis, autoimmune diseases) and glucocorticoid medication. Non trauma exposed control group subjects were also excluded if they met the criteria for any mental disorder according to DSM IV or reported taking psychotropic medication. Individuals with PTSD and trauma exposed controls were excluded if they met the criteria for comorbid alcohol or substance abuse and dependence or a current or past history of a psychosis according to DSM IV. The inflammation load between the time points of assessment was documented, and no severe illnesses were reported in between.

Individuals with PTSD showed no significant group differences from trauma exposed and non trauma exposed controls with respect to age and smoking behavior, but groups differed signifi cantly with respect to gender and intake of psychotropic medica tion (Table 1). Moreover, individuals with PTSD had experienced significantly more different traumatic event types (event list of the Clinician Administered PTSD Scale [CAPS], Blake et al., 1995), significantly more war and torture events (Vivo checklist, Schauer et al., 2011b), and showed higher symptom scores in the CAPS, the Hamilton Depression Rating Scale (HAM D; Hamilton, 1960) and the screening for somatoform symptoms (SOMS 7; Rief and

\footnotetext{
2 Traumatic load index [(number of traumatic event types on the CAPS event list/items on the CAPS event list) + (number of war experiences on the vivo checklist/items on the war checklist) + (number of torture experiences on the vivo checklist/items on the torture checklist)]
} 
Table 1

Socio-demographic and clinical characteristics of PTSD patients assigned to the narrative exposure therapy (NET) and the Waitlist Control (WLC) group as well as of traumaexposed individuals and control subjects.

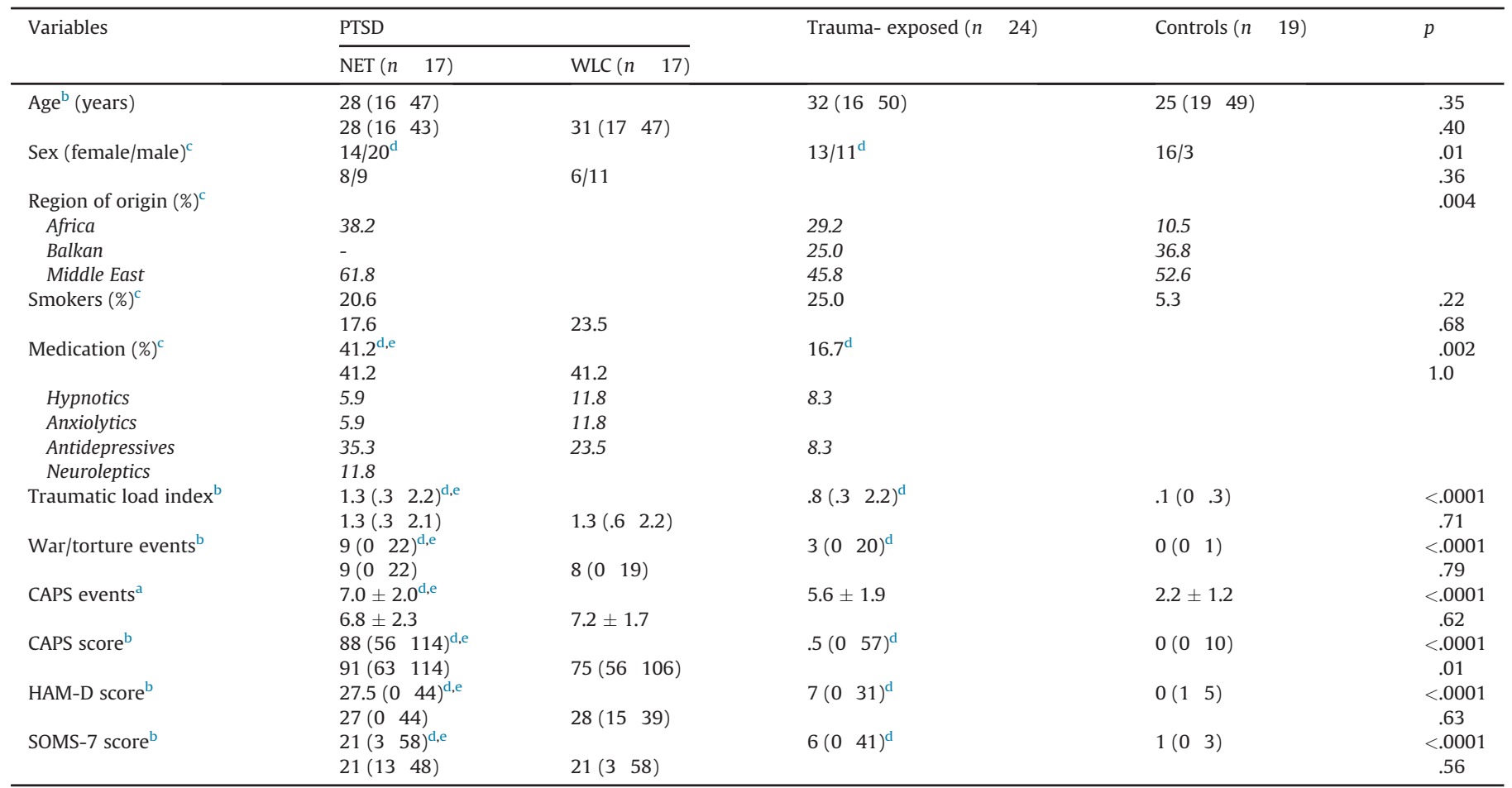

a Group comparisons in continuous variables were performed with ANOVA. Data are presented as mean \pm standard deviation.

b When residuals of the model were not normally distributed, non-parametric testing in continuous variables was done with the Kruskal Wallis test $\left(\chi^{2}\right)$. Data are presented as median and range.

${ }^{c}$ Group comparisons in categorical variables were performed with chi-squared tests $\left(\chi^{2}\right)$. CAPS, Clinician-Administered PTSD Scale; HAM-D, Hamilton Depression Rating Scale; SOMS-7, Screening for Somatoform Symptoms-7.

d Significantly different from non-exposed controls.

e Significantly different from trauma-exposed controls.

Hiller, 2003) than trauma exposed and non exposed controls. Trauma exposed individuals differed significantly from non exposed controls with respect to CAPS, HAM D and SOMS 7 scores (Table 1). In accord with the building block effect of trau matic stress (Kolassa et al., 2010; Neuner et al., 2004a), the trau matic load index correlated positively with PTSD symptom severity $(r \quad .65 ; p<.0001)$.

\subsubsection{Concerning the treatment study}

The NET group and the WLC did not differ significantly with respect to age, sex, ethnicity, smoking behavior or intake of psy chotropic medication, number of traumatic event types experi enced, HAM D score, or SOMS 7 score. However, the NET group showed a significantly higher PTSD symptom score (Table 1).

\subsection{Procedure}

\subsubsection{Baseline screening}

All participants were screened with a clinical diagnostic inter view by trained clinical psychologists from the Center of Excellence for Psychotraumatology in Konstanz, always starting at 10 a.m. If participants were not fluent in English or German, diagnostic in terviews were completed with the help of trained interpreters. The interview started with socio demographic and health related in formation (e.g. smoking behavior, use of psychotropic medication, physical disorders). Then, the number of different traumatic event types experienced and PTSD symptom severity were assessed using the Clinician Administered PTSD Scale (CAPS; Blake et al., 1995). In addition, the Vivo Checklist of War, Detention, and Torture Events
(Schauer et al., 2011b) was administered to assess war and torture experiences in more detail. Depressive symptoms were quantified by the Hamilton Depression Scale (HAM D; Hamilton, 1960) and somatic complaints by a shortened version of the Screening for Somatoform Symptoms (SOMS 7; Rief and Hiller, 2003). Comorbid psychiatric disorders were assessed using the Mini International Neuropsychiatric Interview (MINI; Sheehan et al., 1998). The same clinical diagnostic interview was repeated four and 12 months post test.

\subsubsection{Treatment study}

The trial was conducted in an ambulant setting and therapists were clinical psychologists specialized in the field of trauma and experts for narrative exposure therapy (NET). The 34 individuals with PTSD were randomly assigned to either the NET group or a WLC group. The NET group received 12 weekly treatment sessions of $90 \mathrm{~min}$ (Schauer et al., 2011a). Treatment adherence was moni tored by regular supervision. The WLC group waited for about eight months without any standardized intervention. Post tests were conducted four months $\left(t_{1}\right)$, and one year $\left(t_{2}\right)$ after the end of NET. For the participants in the WLC group, the time spans between pre and post tests were individually matched with the NET group. For ethical reasons, the WLC group received treatment with NET after the first post test, therefore only the NET group was invited to the one year follow up. Participant flow is shown in Fig. 1. The clini cians who performed the outcome evaluations were never the same as the clinician who performed the baseline evaluation or the psychotherapeutic intervention; moreover, the two follow up evaluations were performed by different clinicians. Diagnosticians 


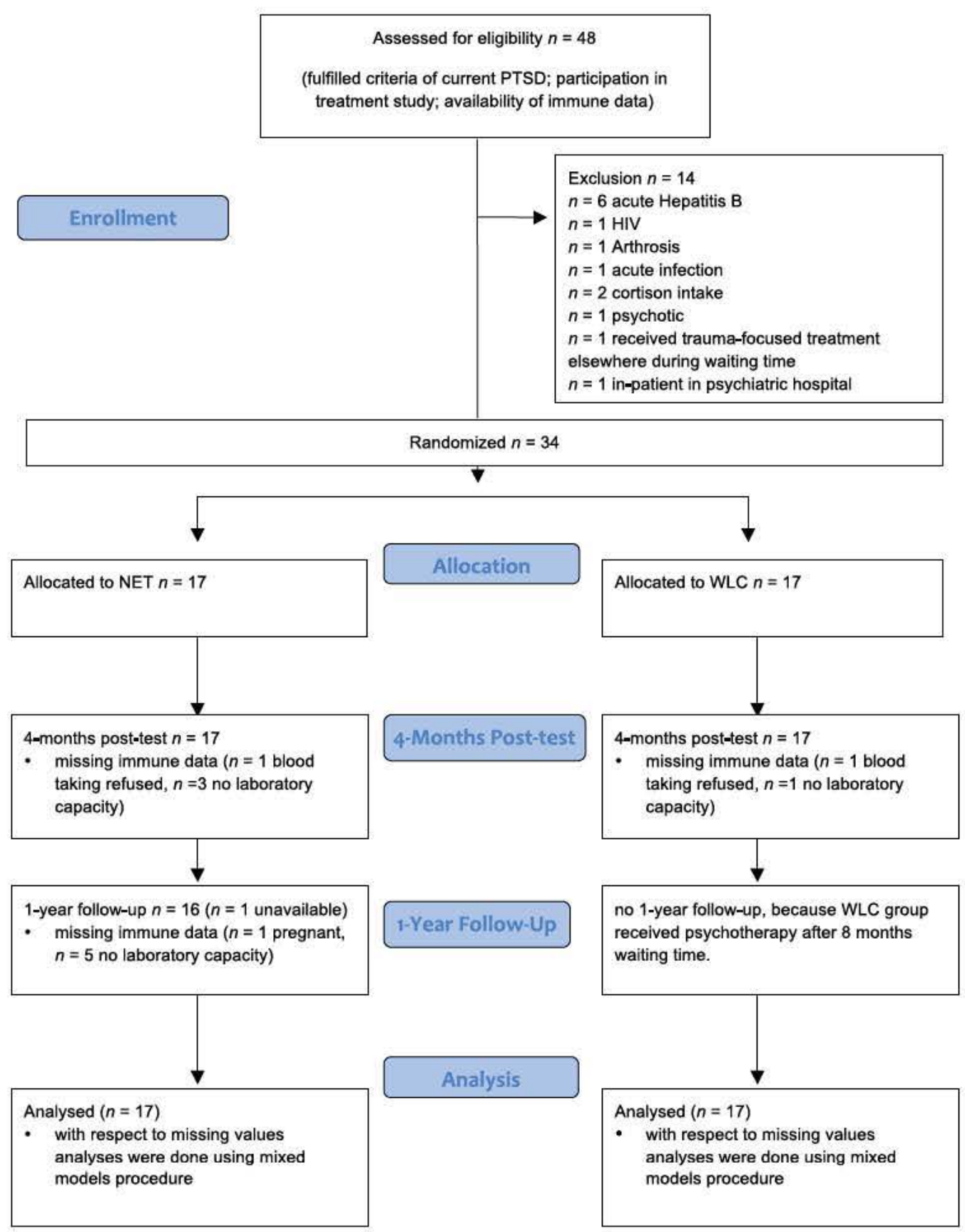

Fig. 1. Flow of participants through the study. PTSD indicates Posttraumatic Stress Disorder; NET indicates Narrative Exposure Therapy and WLC indicates Waitlist Control Group.

were blind with regard to group membership at baseline and at both post tests.

The study was conducted in line with the principles of the Declaration of Helsinki. The University of Konstanz Ethics Commit tee approved the study. All participants provided advance written informed consent and received $30 €$ remuneration for each blood drawing. Treatment with NET was provided for free. The study was registered at http://clinicaltrials.gov/ct2/show/NCT01206790.

\subsection{Blood collection and lymphocyte phenotyping}

Blood drawings and lymphocyte phenotyping were performed before NET started $\left(t_{0}\right)$, four months post treatment $\left(t_{1}\right)$, and one year post treatment $\left(t_{2}\right)$. Blood was collected always at 10:00 a.m. in EDTA buffered tubes. Peripheral blood was sent within $1 \mathrm{~h}$ to the
Laboratory of Immunology, University of Konstanz, Germany, for further processing. Blood samples were coded to guarantee blind ing of the laboratory staff involved. The method used for lympho cyte phenotyping was stringently equal to the method used by Sommershof et al. (2009).

In a first step, the total number of monocytes, granulocytes and lymphocytes were counted in whole peripheral blood samples. Lymphocytes were subdivided into B cells $\left(\right.$ CD19 $\left.9^{+}\right)$, NK cells (CD16 ${ }^{+}$ $\mathrm{CD}_{56}{ }^{+}$), $\mathrm{CD}^{+}{ }^{+}$Tcells, $\mathrm{CD}^{+}{ }^{+} \mathrm{CD} 4^{+} \mathrm{T}$ helper cells, $\mathrm{CD}^{+} \mathrm{CD}^{+}$cytotoxic $\mathrm{T}$ cells, and $\mathrm{CD}^{+} \mathrm{CD}_{25}{ }^{+} \mathrm{FoxP}^{+}{ }^{+} \mathrm{T}_{\text {reg }}$ cells. The surface molecules CD45RA and CCR7 were used to characterize distinct T cell matu ration subsets: naïve $\left(\mathrm{CD}^{2} 5 \mathrm{RA}^{+} \mathrm{CCR}^{+}\right)$, central memory $\left(\mathrm{T}_{\mathrm{CM}}\right.$ : $\left.\mathrm{CD}_{5} \mathrm{RA}^{-} \mathrm{CCR}^{+}\right)$, effector memory $\left(\mathrm{T}_{\mathrm{EM}}\right.$ : $\left.\mathrm{CD}^{-} 5 \mathrm{RA}^{-} \mathrm{CCR} 7^{-}\right)$and CD45RA positive effector memory cells ( $\mathrm{T}_{\mathrm{EMRA}}$ : $\mathrm{CD} 45 \mathrm{RA}^{+} \mathrm{CCR7}^{-}$). For a detailed description of the different classes of $\mathrm{T}$ cells, their 
Table 2

Different classes of T cells, their main function and tissue localization.

\begin{tabular}{|c|c|c|c|}
\hline T Cells & Phenotype & Main function & Tissue localization \\
\hline Naïve & $\operatorname{CD} 45 R A(+) \operatorname{CCR} 7(+)$ & Immune responses to de novo pathogenic organisms & $\begin{array}{l}\text { Circulate between secondary lymphoid } \\
\text { organs via the lymph and blood }\end{array}$ \\
\hline Memory & & $\begin{array}{l}\text { Immune response to recurrent encounters with the } \\
\text { same pathogenic organism }\end{array}$ & \\
\hline Central Memory (CM) & CD45RA(-) CCR7(+) & Secondary effector function; high proliferative potential & $\begin{array}{l}\text { Secondary lymphoid organs (lymph } \\
\text { nodes and spleen) }\end{array}$ \\
\hline Effector Memory (EM) & $\operatorname{CD} 45 R A(-) \operatorname{CCR} 7(-)$ & Immediate effector function; low expansion potential & $\begin{array}{l}\text { Peripheral tissues (lung, liver, intestine, } \\
\text { spleen, and blood) }\end{array}$ \\
\hline $\mathrm{T}_{\text {EMRA }}$ & $\mathrm{CD} 45 \mathrm{RA}(+) \operatorname{CCR} 7(-)$ & Immediate and high effector function; low expansion potential & $\begin{array}{l}\text { Peripheral tissues (lung, liver, intestine, } \\
\text { spleen, and blood) }\end{array}$ \\
\hline Regulatory $\mathrm{T}$ cells $\left(\mathrm{T}_{\text {reg }}\right)$ & $\mathrm{CD} 4(+) \mathrm{CD} 25(+)$ FoxP3(+) & $\begin{array}{l}\text { Controlling immune responses and maintaining self-tolerance } \\
\text { by inhibiting autoreactive } \mathrm{T} \text { cells }\end{array}$ & $\begin{array}{l}\text { Secondary lymphoid organs (lymph } \\
\text { nodes and peripheral tissue) }\end{array}$ \\
\hline
\end{tabular}

main function and their relevance to the current study, please see Table 2.

Absolute numbers of lymphocytes were obtained using an automated hematology analyzer (XT 2000i, Sysmex, Horgen, Switzerland). For a detailed description of lymphocyte phenotyp ing, please see Sommershof et al. (2009).

\subsection{Outcomes}

Outcome measures were changes in PTSD symptom severity (CAPS score), in depressive symptoms (HAM D score), in somatic complaints (SOMS 7 score) and in $\left(\mathrm{CD}_{4} 5 \mathrm{RA}^{+} \mathrm{CCD} 7^{+}\right)$naïve and $\left(\mathrm{CD} 4 \mathrm{RA}^{-}\right)$memory subsets of $\mathrm{CD}^{+}, \mathrm{CD}^{+}$, and $\mathrm{CD} 8^{+} \mathrm{T}$ cells as well as in $\mathrm{CD} 4^{+} \mathrm{CD} 25^{+} \mathrm{FoxP}^{+} \mathrm{T}_{\text {reg }}$ cells four months and one year after NET.

\subsection{Statistics}

\subsubsection{Group differences at baseline ( $\left.t_{0}\right)$}

Differences between groups (PTSD, trauma exposed controls, non exposed controls) in clinical characteristics and T cell distri butions were analyzed by ANOVA. As age influences $\mathrm{T}$ cell distri bution (Fagnoni et al., 2000; Hong et al., 2004), age was included as a covariate in the models as also suggested by AIC (Burnham et al., 2002). Including smoking and gender or excluding participants taking psychotropic medication did not alter results.

The Kruskal-Wallis test was used to analyze group differences when ANOVA residuals were not normally distributed. As we had specific hypotheses for the direction of T cell changes (reduction in the proportion of $\mathrm{CD}^{+}$naïve and $\mathrm{T}_{\text {reg }}$ cells), one sided independent $t$ tests or the Wilcoxon-Mann-Whitney test were used for post hoc analyses for these variables. Correlations were analyzed with the Kendall tau rank correlation.

\subsubsection{Treatment study}

Linear mixed models were used to analyze changes in clinical characteristics and lymphocyte differentiations from $t_{0}$ to $t_{1}$. Age was included as covariate for T cell analysis. Since residuals in the model of $\mathrm{CD}^{+}$total $\mathrm{T}$ cells and $\mathrm{CD}^{+}$memory $\mathrm{T}$ cells were not normally distributed, data were retested with a logarithmized data set and results remained stable. Changes from $t_{0}$ to $t_{1}$ and $t_{2}$ within the NET group were analyzed by linear mixed models and paired $t$ tests for post hoc comparisons. Treatment effect sizes were calcu lated by Hedges' $g$ (Hedges, 1981).

\section{Results}

\subsection{The effect of traumatic stress and PTSD on T cell distribution at $t_{0}$}

There was no difference in the absolute cell number of lym phocytes $\left(\begin{array}{lll}\chi^{2} & .72 ; p & .70\end{array}\right)$ between individuals with PTSD (me dian 1939, range 1249-2800), trauma exposed individuals (median 1960, range 1301-2938), and non traumatized controls (median 1815, range 1308-2965), but the percentage of total CD3 ${ }^{+}$ T cells was significantly reduced in individuals with PTSD compared to non traumatized controls (Table 3). Extending the results of Sommershof et al. (2009), we found a significant main effect for

Table 3

T Lymphocyte distribution in whole peripheral blood of individuals with PTSD, of trauma-exposed individuals and of control subjects, at baseline ( $\left.t_{0}\right)$.

\begin{tabular}{|c|c|c|c|c|c|c|c|c|c|}
\hline \multirow[t]{2}{*}{ Variables (\%) } & \multicolumn{2}{|c|}{ PTSD $(n \quad 34)$} & \multicolumn{2}{|c|}{ Trauma-exposed ( $n \quad 24)$} & \multicolumn{2}{|c|}{ Controls ( $n \quad 19)$} & \multicolumn{2}{|c|}{ Statistics } & \multirow[t]{2}{*}{$p$} \\
\hline & $M$ & SD & $M$ & SD & $M$ & $\mathrm{SD}$ & & & \\
\hline \multicolumn{10}{|l|}{$\mathrm{CD3}^{+}$} \\
\hline Total $^{\mathrm{a}}$ & $68.6^{\mathrm{c}}$ & 36.579 .6 & $66.2^{c}$ & $40.0 \quad 78.3$ & 73.9 & 51.478 .1 & \multicolumn{2}{|c|}{$\chi^{2} \quad 7.03$} & .03 \\
\hline Naïve ${ }^{\mathrm{b}}$ & 34.9 & 11.4 & 37.1 & 9.6 & 41.0 & 12.8 & $\hat{F}_{(2,72)}$ & 1.89 & .16 \\
\hline CD45RA memory ${ }^{\mathrm{b}}$ & $41.5^{\mathrm{c}}$ & 9.9 & 39.0 & 8.1 & 34.5 & 9.4 & $F_{(2,72)}$ & 3.70 & .03 \\
\hline $\mathrm{T}_{\text {EMRA }}{ }^{\mathrm{a}}$ & 21.9 & $8.5 \quad 40.3$ & 23.4 & $3.9 \quad 48.5$ & 20.2 & 8.453 .5 & $\chi^{2} .1$ & & .92 \\
\hline \multicolumn{10}{|l|}{$\mathrm{CDB}^{+}$} \\
\hline Total $^{\mathrm{b}}$ & 22.0 & 5.3 & 23.1 & 5.3 & 25.4 & 5.1 & $F_{(2,70)}$ & 2.64 & .08 \\
\hline Naïve ${ }^{\mathrm{b}}$ & $30.8^{c}$ & 12.7 & $30.9^{c}$ & 13.2 & 41.0 & 19.5 & $F_{(2,68)}$ & 3.72 & .03 \\
\hline CD45RA memory ${ }^{\mathrm{a}}$ & $31.7^{\mathrm{c}, \mathrm{d}}$ & $12.2 \quad 61.4$ & 24.1 & $10.4 \quad 52.3$ & 23.5 & 10.146 .8 & $\chi^{2} 8$ & & .01 \\
\hline $\mathrm{T}_{\text {EMRA }} \mathrm{b}^{\mathrm{s}}$ & 36.6 & 13.2 & 43.4 & 15.5 & 34.9 & 15.5 & $\hat{F}_{(2,68)}$ & 1.99 & .14 \\
\hline \multicolumn{10}{|l|}{$\mathrm{CD4}^{+}$} \\
\hline Total $^{\mathrm{b}}$ & 35.9 & 7.9 & 39.2 & 7.0 & 39.1 & 8.1 & $F_{(2,72)}$ & 1.68 & .19 \\
\hline Naïve ${ }^{b}$ & 43.6 & 13.7 & 43.6 & 12.3 & 48.6 & 11.9 & $F_{(2,70)}$ & 1.07 & .35 \\
\hline CD45RA memory ${ }^{\mathrm{b}}$ & 53.7 & 13.1 & 52.7 & 12.4 & 46.9 & 11.8 & $F_{(2,70)}$ & 1.84 & .17 \\
\hline $\mathrm{T}_{\text {EMRA }}{ }^{\mathrm{a}}$ & 1.7 & .512 .1 & 2.8 & .211 .8 & 1.9 & .617 .9 & $\chi^{2} 2$ & & .24 \\
\hline $\mathbf{T}_{\text {regulatory }}{ }^{\mathrm{a}}\left(\mathrm{CD} 4^{+} \mathrm{CD} 5^{+} \mathrm{FoxP}^{+}\right)$ & $1.4^{\mathrm{c}, \mathrm{d}}$ & .55 .0 & 2.7 & $1.2 \quad 4.0$ & 2.4 & $1.0 \quad 3.5$ & $\hat{\chi^{2}}$ & & .007 \\
\hline
\end{tabular}

${ }^{a}$ Residuals of the model were not normally distributed; median and range are displayed; non-parametric testing was done with the Kruskal Wallis test ( $\chi^{2}$ ).

b Analysis were done with age as covariate using ANCOVA; means and standard deviations (SD) are displayed.

c Significantly different from non-exposed controls.

d Significantly different from trauma-exposed controls. 
Group with respect to the percentage of naïve $\mathrm{CD}^{+} \mathrm{T}$ cells $(F(2,68) \quad 3.72 ; p \quad .03)$, with post hoc tests revealing significant group differences between individuals with PTSD and non traumatized controls $\left(t_{(27.0)} \quad 2.04 ; p \quad .04\right.$; one sided) and be tween trauma exposed subjects and controls $\left(t_{(31.5)} \quad 1.87 ; p \quad .03\right.$; one sided), but not between individuals with PTSD and trauma exposed controls $\left(t_{(38.9)} \quad .04 ; p \quad .49\right.$; one sided; see Table 3$)$ Again, there was a significantly increased percentage of memory
$\mathrm{CD}^{+} \mathrm{T}$ cells in individuals with PTSD compared to non PTSD controls $\left(\chi^{2} \quad 8.65 ; p \quad .01\right)$. Post hoc tests revealed significant group differences between individuals with PTSD and non traumatized controls ( $W \quad 181.5 ; p \quad .005$; one sided) and be tween individuals with PTSD and trauma exposed subjects ( $W \quad 456.0 ; p \quad .01$; one sided), but not between trauma exposed subjects and controls ( $W \quad 171 ; p \quad .31$; one sided). Furthermore, we confirmed the reduction in the percentage of $\mathrm{T}_{\text {reg }}$ cells in
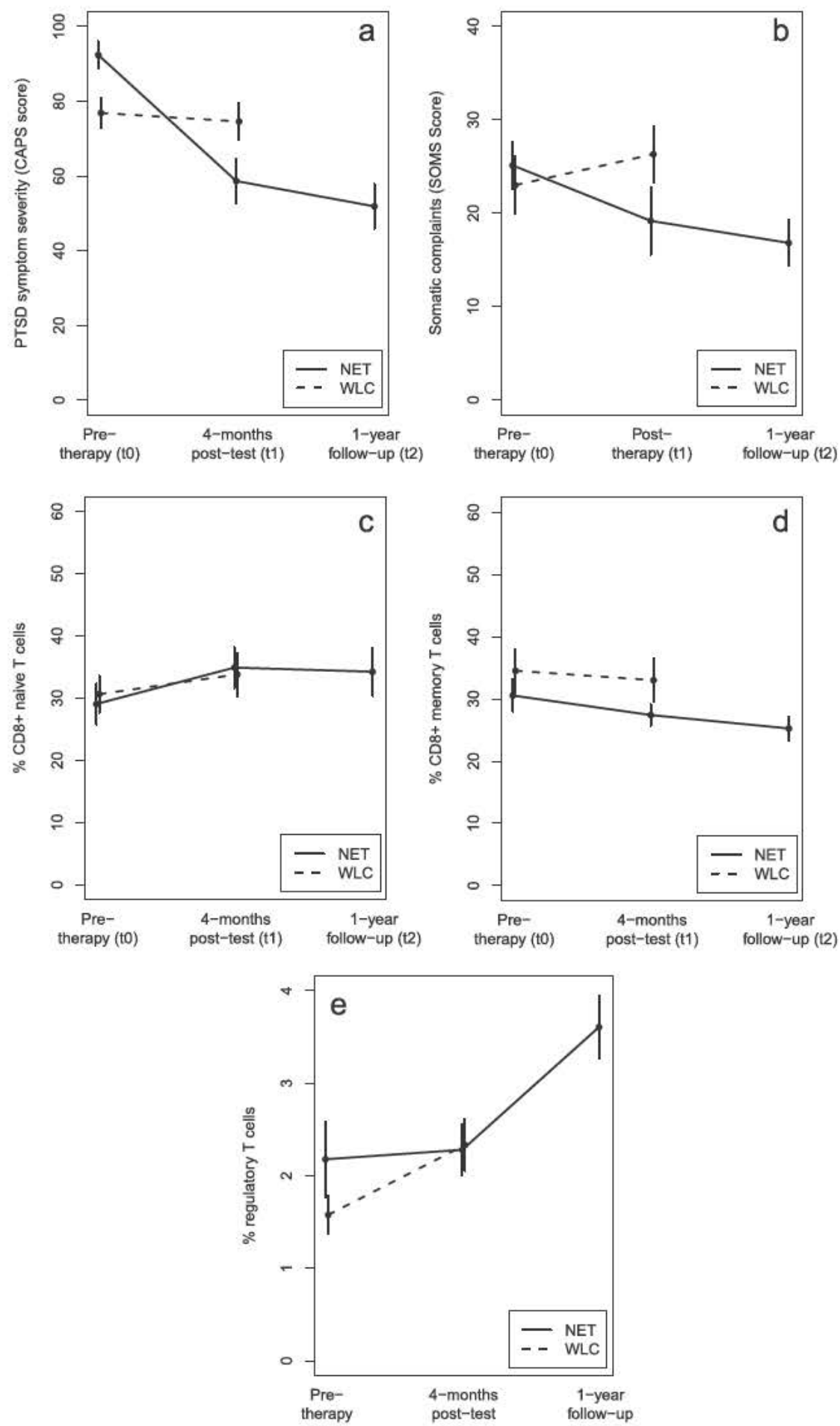

Fig. 2. a) PTSD symptom severity (CAPS score), b) somatic complaints (SOMS-7 score) c) percentages of (CD45RA+CCR7 ${ }^{+}$) nailve CD8 ${ }^{+} \mathrm{T}$ cells and d) percentages of (CD45RA ) memory $\mathrm{CD}^{+} \mathrm{T}$ cells in the narrative exposure therapy (NET) group and the Waitlist Control (WLC) group pre-therapy $\left(t_{0}\right)$, 4-months post $\left(t_{1}\right)$ and 1 -year post-treatment $\left(t_{2}\right)$ e) percentages of $\left(\mathrm{CD}^{+} \mathrm{CD}_{2} 5^{+} \mathrm{FOXP3}^{+}\right)$regulatory $\mathrm{T}$ cells in the NET and WLC subgroups parallelized for baseline $\mathrm{T}_{\text {reg }}$ numbers. 
individuals with PTSD $\left(\chi^{2} \quad 9.79 ; p \quad .007\right): \mathrm{T}_{\text {reg }}$ cells were significantly reduced in the PTSD compared to the non traumatized control group ( $W \quad 140.5 ; Z \quad 1.9 ; p \quad .03$; one sided); similarly, individuals with PTSD showed a larger reduction in $T_{\text {reg }}$ cells than

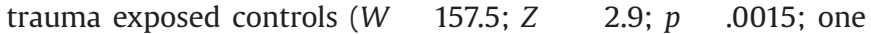
sided); there was no significant difference between trauma exposed subjects and the control group $\left(\begin{array}{lll}W & 111 ; Z & 1.0 \text {; }\end{array}\right.$ $p$.15; one sided). No significant group differences were found for the percentage of total $\mathrm{CD}^{+}$or $\mathrm{CD}^{+} \mathrm{T}_{\mathrm{EMRA}}$ cells as well as for the percentage of total $\mathrm{CD} 4^{+}, \mathrm{CD} 4^{+}$naïve, memory and $\mathrm{T}_{\mathrm{EMRA}}$ cells (see Table 3).

The number of different traumatic event types experienced correlated negatively with the percentage of naïve $\mathrm{CD} 8^{+} \mathrm{T}$ cells

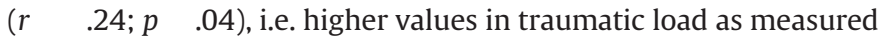
by the traumatic load index were associated with a stronger reduction in naïve $\mathrm{CD}^{+} \mathrm{T}$ cells.

\subsection{Effects of NET on T cell distribution}

Four months after treatment, PTSD symptom severity (CAPS sum score) had declined significantly in the NET compared to the WLC group (Time $\times$ Treatment $F_{(1,32)} \quad 16.90 ; p \quad .0003$ ). The effect size of treatment in the NET group was large (Hedges' $g$ 1.61). Post hoc tests showed a significant decline in symptom severity in the NET group from $t_{0}$ to $t_{1}\left(t_{(16)} \quad 5.99 ; p<.0001\right)$, whereas symptom severity remained stable in the WLC group. At $t_{2}$, the NET group showed an even greater decline in symptoms (Time $\left.F_{(1,32)} \quad 32.04 ; p \quad .0001\right)$ with an effect size of Hedges' $g \quad 1.96$ from $t_{0}$ to $t_{2}$ (Fig. 2a). NET also improved somatic symptoms, as measured with the SOMS 7, in the treatment but not in the WLC group (Time $\times$ Treatment, $F_{(1,31)} \quad 6.19 ; p \quad .02$; Fig. 2 b). However, depressive symptoms (HAM D) were not significantly improved in the NET compared to the WLC group (Time $\times$ Treatment, $F_{(1,32)} \quad .89 ; p \quad .35$, see Table 4$)$.
Against our hypothesis, there was no treatment specific in crease in the percentage of naïve $\mathrm{CD}^{+} \mathrm{T}$ cells from $t_{0}$ to $t_{1}$ (Time $\times$ Treatment $F_{(1,25)} \quad .05 ; p \quad .82$, Table 4 and Fig. $2 \mathrm{c}$ ), or from $t_{0}$ to $t_{2}$ within the PTSD group (Time $F_{(1,21)} \quad 2.17 ; p \quad .16$ ). Furthermore, there were no treatment specific alterations in the percentage of memory $\mathrm{CD}^{+} \mathrm{T}$ cells in the NET, compared to the WLC group (Time $\times$ Treatment $\left.F_{(1,25)} \quad .60 ; p \quad .45\right)$ and no sig nificant changes in the percentage of memory $\mathrm{CD}^{+} \mathrm{T}$ cells over time (Time $F_{(1,21)} .28 ; p \quad .60$ ) within the NET group (see Fig. $2 \mathrm{~d}$ ).

With respect to the percentage of $T_{\text {reg }}$ cells, we found no Time $\times$ Treatment interaction $\left(F_{(1,23)} \quad 3.06 ; p \quad .09\right)$ from $t_{0}$ to $t_{1}$ (Table 4), and no significant increase in the percentage of $\mathrm{T}_{\text {reg }}$ over time (Time $\left.F_{(1,20)} \quad 3.40 ; p \quad .08\right)$ within the NET group. However there was a significant time effect from $t_{1}$ to $t_{2}$ within the NET group $\left(t_{(6)} \quad 2.37 ; p \quad .05\right)$. Since the NET and the WLC group differed significantly at $t_{0}$ in $\mathrm{T}_{\text {reg }}$ cell counts $\left(t_{(22.7)} \quad 2.24\right.$; $p \quad .04)$, which could have induced spurious effects through regression to the mean, we performed an additional analysis excluding the two subjects with the highest percentage of $\mathrm{T}_{\text {regs }}$ in the NET and the two subjects with the lowest percentage of $T_{\text {regs }}$ in the WLC group, parallelizing groups with respect to $T_{\text {reg }}$ cell counts $\left(t_{(20.6)} \quad 1.32 ; p \quad .20\right)$. Again, there was no Time $\times$ Treatment interaction from $t_{0}$ to $t_{1}\left(F_{(1,19)} \quad .85 ; p \quad .37\right)$, but the NET group showed a significant increase in $\mathrm{T}_{\text {regs }}$ over time (Time $F_{(1,17)} \quad 8.06 ; p \quad .01$; Fig. 2e). Post hoc tests revealed a significant increase from $t_{0}$ to $t_{2}\left(t_{(7)} \quad 1.45 ; p \quad .05\right)$ and from $t_{1}$ to $t_{2}\left(t_{(5)} \quad 2.56 ; p \quad .05\right)$, but not from $t_{0}$ to $t_{1}$. Furthermore, there was a marginally significant but large positive association be tween PTSD symptom reduction from $t_{0}$ to $t_{2}$ and the increase of $\mathrm{T}_{\text {regs }}$ from $t_{0}$ to $t_{2}\left(\begin{array}{lll}r & .75 ; p & .09\end{array}\right)$.

No treatment specific alterations were found for the other T cell subtypes investigated (see Table 4) except for the total percentage of $\mathrm{CD}^{+} \mathrm{T}$ cells, increasing significantly from $t_{0}$ to $t_{2}$ within the NET group $\left(F_{(1,22)} \quad 6.53 ; p \quad .02\right)$.

Table 4

Changes in clinical characteristics and T cell distribution in the narrative exposure therapy (NET) and the Waitlist Control (WLC) group.

\begin{tabular}{|c|c|c|c|c|c|c|c|}
\hline \multirow{2}{*}{$\begin{array}{l}\text { Variables } \\
\text { CAPS }\end{array}$} & \multirow{2}{*}{$\begin{array}{l}\text { Group } \\
\text { NET }\end{array}$} & \multirow{2}{*}{$\begin{array}{l}\text { Pre-therapy } M(\mathrm{SD}) \\
92.41^{\mathrm{b}}(14.95)\end{array}$} & \multirow{2}{*}{$\begin{array}{l}\text { 4-months Post } M(\mathrm{SD}) \\
58.65(24.93)\end{array}$} & \multirow{2}{*}{$\frac{1 \text {-year post } M(\mathrm{SD})}{51.88(24.52)}$} & \multicolumn{2}{|c|}{ Statistics (treatment $\times$ time) } & \multirow{2}{*}{$\frac{p}{.0003}$} \\
\hline & & & & & $F_{(1,32)}$ & 16.90 & \\
\hline & WLC & $76.88(15.95)$ & $74.59(20.42)$ & & & & \\
\hline \multirow[t]{2}{*}{ HAM-D } & NET & $22.82(11.73)$ & $17.00(9.81)$ & $17.63(9.84)$ & $F_{(1,32)}$ & .89 & .35 \\
\hline & WLC & $25.94(6.55)$ & $24.18(9.21)$ & & & & \\
\hline \multirow[t]{2}{*}{ SOMS } & NET & $25.12(10.55)$ & $19.18(14.93)$ & $16.81(10.00)$ & $F_{(1,31)}$ & 6.19 & .02 \\
\hline & WLC & $23.00(12.75)$ & $26.31(12.38)$ & & & & \\
\hline \multirow[t]{2}{*}{$\%$ CD3 total ${ }^{\mathrm{a}}$} & NET & $65.10(11.18)$ & $67.65(12.57)$ & $69.05(6.04)$ & $F_{(1,25)}$ & .17 & .68 \\
\hline & WLC & $65.53(7.54)$ & $65.25(11.45)$ & & & & \\
\hline \multirow[t]{2}{*}{ \% CD3 naïve } & NET & 35.11 (11.69) & $38.36(11.38)$ & $35.61(12.31)$ & $F_{(1,26)}$ & .00 & .98 \\
\hline & WLC & $34.71(12.05)$ & 36.73 (12.59) & & & & \\
\hline \multirow[t]{2}{*}{$\% \mathrm{CD} 3$ memory } & NET & $40.15(9.01)$ & $40.19(9.23)$ & $40.15(11.03)$ & $F_{(1,26)}$ & .08 & .78 \\
\hline & WLC & $42.94(10.15)$ & $44.73(12.11)$ & & & & \\
\hline \multirow[t]{2}{*}{$\%$ CD8 total } & NET & $23.96^{\mathrm{b}}(5.55)$ & $23.64(4.70)$ & $23.72(6.89)$ & $F_{(1,26)}$ & .34 & .56 \\
\hline & WLC & $20.17(4.52)$ & $20.99(5.40)$ & & & & \\
\hline \multirow[t]{2}{*}{ \% CD8 naive } & NET & $29.06(13.42)$ & $34.91(13.42)$ & $34.24(15.93)$ & $F_{(1,25)}$ & .07 & .80 \\
\hline & WLC & $30.63(12.33)$ & $33.82(14.21)$ & & & & \\
\hline \multirow[t]{2}{*}{$\%$ CD8 memory } & NET & $30.55(10.58)$ & $27.41(7.16)$ & $25.26(7.80)$ & $F_{(1,25)}$ & .60 & .45 \\
\hline & WLC & $34.53(14.42)$ & 32.61 (13.67) & & & & \\
\hline \multirow[t]{2}{*}{$\%$ CD4 total } & NET & $34.54(7.13)$ & $38.23(5.49)$ & $39.03(6.52)$ & $F_{(1,25)}$ & .05 & .83 \\
\hline & WLC & $38.02(8.71)$ & $42.04(6.52)$ & & & & \\
\hline \multirow[t]{2}{*}{ \% CD4 naïve } & NET & 43.29 (16.39) & 42.28 (15.99) & $43.17(15.72)$ & $F_{(1,25)}$ & .29 & .61 \\
\hline & WLC & $42.06(13.54)$ & $38.01(14.57)$ & & & & \\
\hline \multirow[t]{2}{*}{ \% CD4 memory } & NET & $53.84(15.26)$ & $55.99(15.03)$ & $55.11(15.29)$ & $F_{(1,25)}$ & .05 & .82 \\
\hline & WLC & $55.28(13.37)$ & $59.37(14.42)$ & & & & \\
\hline \multirow[t]{2}{*}{$\% \mathrm{~T}$ reg } & NET & $2.50^{\mathrm{b}}(1.73)$ & $2.42(1.02)$ & $3.54(1.25)$ & $F_{(1,23)}$ & 3.06 & .09 \\
\hline & WLC & $1.46(.81)$ & $2.35(1.04)$ & & & & \\
\hline
\end{tabular}

Abbreviations: CAPS, Clinical Administered PTSD Scale; HAM-D, Hamilton Depression Rating Scale; SOMS, Screening for Somatoform Symptoms; Statistics: M (mean), SD (standard deviation). Age was included as covariate into the models of T cell analysis.

a Since residuals of the model were not normally distributed, data were retested with a logarithmized data set and results remained stable.

b Significantly different from WLC at $t_{0}$. 


\section{Discussion}

Extending the findings of Sommershof et al. (2009) in a larger sample, we found a decreased proportion of $\left(C D 45 R A^{+} C C R 7^{+}\right)$ naïve $\mathrm{CD} 8^{+} \mathrm{T}$ cells, an increased proportion of $\left(\mathrm{CD} 45 \mathrm{RA}^{-}\right)$memory $\mathrm{CD}^{+} \mathrm{T}$ cells, and a decreased proportion of $\mathrm{CD} 4^{+} \mathrm{CD} 25^{+} \mathrm{FOXP} 3^{+} \mathrm{T}_{\mathrm{reg}}$ cells at baseline in individuals with PTSD compared to controls with no or little trauma exposure. Moreover, trauma exposed non PTSD subjects showed a significantly lower proportion of naïve $\mathrm{CD}^{+} \mathrm{T}$ cells than non exposed controls, and the number of traumatic event types experienced was significantly negatively correlated with the percentage of naïve $\mathrm{CD}^{+} \mathrm{T}$ cells, indicating a cumulative effect of exposure to traumatic stressors. As we found no differ ences between non PTSD subjects with or without trauma expo sure with respect to $T_{\text {reg }}$ cells, we propose that the reduction of naïve $\mathrm{CD} 8^{+} \mathrm{T}$ cells is a consequence of trauma burden rather than an explicit feature of PTSD, whereas alterations in regulatory T cells seem to be specifically associated with the chronic stress experi enced by individuals with PTSD. The decrease in naïve and the increase in memory $\mathrm{CD}^{+} \mathrm{T}$ cells in individuals with PTSD are in accordance with a $\mathrm{T}$ lymphocyte distribution typical for older in dividuals (Dorshkind et al., 2009; Fagnoni et al., 2000; Hong et al., 2004). Therefore, the alterations in T lymphocyte distributions in individuals with PTSD might indicate a process of premature immunosenescence, which is in line with previous findings showing that psychological stress is associated with immunological aging (Bosch et al., 2009; Epel et al., 2004; Kiecolt Glaser et al., 2003). This immunosenescence might be related to a higher wear and tear of the immune system, as the consequences of chronic/ traumatic stress may be reflected in a blunted immunity that in creases the probability for diseases and associated inflammation responses.

NET led to reduced PTSD symptoms four months after treatment and even further in the one year follow up and improved somatic complaints such as headache, diarrhea, nausea or unspecific chronic pain conditions - consistent with the reported benefits of NET on physical health conditions (Neuner et al., 2008). Depressive symptoms did not improve through NET. The reduced proportion of $\mathrm{CD}^{+} \mathrm{CD}^{2} 5 \mathrm{RA}^{+} \mathrm{CCR}^{+}$naïve T lymphocytes in PTSD did not increase through treatment, suggesting that the shift in the proportion of naïve and memory $T$ lymphocytes in individuals with PTSD is not reversible and thus might render these patients permanently more susceptible to infectious diseases (Fagnoni et al., 2000; Shen et al., 1999). In accordance with our outcomes, $\mathrm{CD}^{+} \mathrm{T}$ lymphocytes have been reported to be stable over time and not affected by psycho therapeutic interventions in cancer or HIV patients (Carrico et al., 2005; Hosaka et al., 2000).

However, the reduced proportion of $\mathrm{CD}^{+} \mathrm{CD}^{+} 5^{+} \mathrm{FOXP} 3^{+} \mathrm{T}_{\text {reg }}$ cells increased with symptom improvement in the NET group at the one year follow up when comparing subgroups matched for baseline cell numbers. $T_{\text {reg }}$ cells, originally termed suppressor $\mathrm{T}$ cells, are essential for controlling immune responses and main taining self tolerance by inhibiting autoreactive T cells. A decrease in number or function of peripheral $\mathrm{T}_{\text {reg }}$ cells has been associated with the development of autoimmune diseases, such us multiple sclerosis, asthma, type 1 diabetes, psoriasis, and rheumatoid arthritis (Costantino et al., 2008). Interestingly, antidepressant medication in individuals suffering from a depressive episode improved not only depressive symptoms but increased also $T_{\text {reg }}$ $\left(\mathrm{CD}^{+}{ }^{+} \mathrm{CD} 25^{\mathrm{hi}}\right)$ cell counts (Himmerich et al., 2010). Moreover, autoimmune diseases seem to react favorably to psychological in terventions (Carlson, 2012). Finally, therapeutic intervention studies focusing on selective enhancement of antigen specific $T_{\text {reg }}$ populations in vitro or in vivo have become a promising target for novel immunotherapeutic approaches in order to reduce or prevent immune mediated pathologies in human autoimmune diseases (Cools et al., 2007). Considering the fundamental role of $\mathrm{T}_{\text {reg }}$ cells in controlling both immunity and tolerance, it will be important to establish whether restoration of $\mathrm{T}_{\text {reg }}$ numbers by psychothera peutic treatment can prevent the induction of autoimmune pa thology or even reverse established disease in PTSD patients.

Limiting factors for the interpretation of our data are: 1) the lack of a one year follow up in the WLC group; 2) missing information about $\mathrm{T}$ cell distributions in healthy controls four months and one year after the baseline assessment. Yet, in a study with healthy university students, $\mathrm{T}$ cell subpopulations remained stable over a period of 3 months free of examinations (Hamuni et al., submitted for publication); 3) The intake of psychotropic medication in about $40 \%$ of the individuals with PTSD, which was, however, equally distributed across groups before and after treatment and thus should not be able to be the factor accounting for the observed effects. 4) The relatively small sample size; and 5) the varied eth nicities of study participants. However, since treatment with NET has been shown to be effective in various populations all over the world (Robjant and Fazel, 2010), we can assume that there is no cultural difference in the biological processing of traumatic stress; 5) We investigated a severely traumatized PTSD sample with high symptom scores, allowing us to study consequences of extreme stress. However, treatment with NET in such an affected sample resulted only in a significant reduction of symptoms, but not in a full recovery from PTSD (58.8\% of the NET group still fulfilled PTSD criteria four months post test). Moreover, individuals with PTSD continued to live under stressful life circumstances (e.g. $88.2 \%$ of the individuals with PTSD have an insecure asylum status and fear deportation). These factors might have precluded stronger therapy effects concerning $\mathrm{T}$ cell maturations subsets and might also explain the persistence of depressive symptoms.

In conclusion, some biological consequences of traumatic stress, such as the shift in the proportion of naïve and memory $\mathrm{T}$ lym phocytes, seem to not be reversible through trauma focused psy chotherapy, while other consequences such as the reduction of $\mathrm{T}_{\text {reg }}$ cells similar to the increased level of DNA damage in peripheral blood mononuclear cells of PTSD patients seem to be alterable through therapy (Morath et al., in press). Further studies on the long term effects of psychotherapy on the immune system are necessary. If the results of this study can be replicated, this would underline the need for effective treatment of PTSD in trauma affected populations to prevent the manifestation of secondary physical diseases in the long run.

\section{Contributors}

J Morath, H Gola and A Sommershof contributed equally to this interdisciplinary work. J Morath and H Gola coordinated the psy chological part of the study; A Sommershof coordinated the bio logical part of the study. J Morath recruited study participants, carried out a large number of the clinical interviews and psycho therapies, performed statistical analyses and drafted the manu script. H Gola prepared the study, recruited study participants, carried out a large number of the clinical interviews and psycho therapies and revised the manuscript. A Sommershof carried out the biological analyses and revised the manuscript critically for important biological content. G Hamuni and $\mathrm{H}$ Adenauer carried out clinical interviews and psychotherapies. C Catani, M Ruf Leuschner, M Schauer carried out clinical interviews and psycho therapies and supervised clinical work. S Kolassa programmed $\mathrm{R}$ scripts, supervised statistical analyses, and drafted the manuscript with a focus on the statistics. M Groettrup, IT Kolassa and T Elbert designed the study, interpreted the study and revised the manu script. In addition, IT Kolassa supervised every step of this study and 
acquired funding by the German Research Foundation (DFG). All authors read and approved the final version of the manuscript.

\section{Conflict of interest}

The authors whose names are listed immediately below certify that they have NO affiliations with or involvement in any organi zation or entity with any financial interest (such as honoraria; educational grants; participation in speakers' bureaus member ship; employment, consultancies, stock ownership, or other equity interest; and expert testimony or patent licensing arrangements), or non financial interest (such as personal or professional re lationships, affiliations, knowledge or beliefs) in the subject matter or material discussed in this manuscript.

\section{Role of funding source}

This study was funded by the German Research Foundation (DFG) Research Unit FOR751 and the European Refugee Fund. The funding source had no involvement in study design; in the collec tion, analysis, and interpretation of data; in the writing of the report; and in the decision to submit the paper for publication.

\section{Acknowledgment}

We thank Frank Neuner for clinical supervision and treatment of patients and Heike Riedke, and Christiane Wolf for technical assistance.

\section{References}

Altemus M, Dhabhar FS, Yang R. Immune function in PTSD. Annals of the New York Academy of Sciences 2006;1071:167 83 .

Antoni MH, Carrico AW, Durán RE, Spitzer S, Penedo F, Ironson G, et al. Randomized clinical trial of cognitive behavioral stress management on human immunodeficiency virus viral load in gay men treated with highly active antiretroviral therapy. Psychosomatic Medicine 2006;68:143 51.

Bennett C, Christie J, Ramsdell F, ME B, Ferguson P, Whitesell L, et al. The immune dysregulation, polyendocrinopathy, enteropathy, X-linked syndrome (IPEX) is caused by mutations of FOXP3. Nature Genetics 2001;27:20 1 .

Blake DD, Weathers FW, Nagy LM, Kaloupek DG, Gusman FD, Charney DS, et al. The development of a clinician-administered PTSD scale. Journal of Traumatic Stress 1995;8:75 90

Bohus M, Dyer AS, Priebe K, Krüger A, Kleindienst N, Schmahl C, et al. Dialectical behaviour therapy for post-traumatic stress disorder after childhood sexual abuse in patients with and without borderline personality disorder: a randomised controlled trial. Psychotherapy and Psychosomatics 2013;82:221 33.

Boscarino J. Posttraumatic stress disorder and physical illness: results from clinical and epidemiologic studies. Annals of the New York Academy of Sciences 2004; 1032:141 53 .

Boscarino J, Chang J. Higher abnormal leukocyte and lymphocyte counts 20 years after exposure to severe stress: research and clinical implications. Psychosomatic Medicine 1999;61:378 86.

Boscarino J, Forsberg CW, Goldberg J. A twin study of the association between PTSD symptoms and rheumatoid arthritis. Psychosomatic Medicine 2010;72:481 6.

Bosch JA, Fischer JE, Fischer JC. Psychologically adverse work conditions are associated with CD8 $+\mathrm{T}$ cell differentiation indicative of immunesenescence. Brain, Behavior, and Immunity 2009;23:527 34.

Buckner J. Mechanisms of impaired regulation by CD4+ CD25+ FOXP3+ regulatory $\mathrm{T}$ cells in human autoimmune diseases. Nature Reviews in Immunology 2010;10:849 59

Burnham KP, Anderson DR. Model selection and multi-model inference: a practical information theoretic approach. Springer; 2002.

Carlson LE. Mindfulness-based interventions for physical conditions: a narrative review evaluating levels of evidence. ISRN Psychiatry 2012;2012:1 21.

Carrico AW, Antoni MH, Pereira DB, Fletcher MA, Klimas N, Lechner SC, et al. Cognitive behavioral stress management effects on mood, social support, and a marker of antiviral immunity are maintained up to 1 year in HIV-infected gay men. International Journal of Behavioral Medicine 2005;12:218 26.

Cloitre M. Effective psychotherapies for posttraumatic stress disorder: a review and critique. CNS Spectrums 2009; 14:32 43

Cools N, Ponsaerts P, Van Tendeloo VFI, Berneman ZN. Regulatory t cells and human disease. Clinical and Developmental Immunology; 2007:89195.

Costantino CM, Baecher-Allan CM, Hafler DA. Human regulatory T cells and autoimmunity. European Journal of Immunology 2008;38:921 4.
Creswell JD, Myers HF, Cole SW, Irwin MR. Mindfulness meditation training effects on $\mathrm{CD} 4+\mathrm{T}$ lymphocytes in HIV-1 infected adults: a small randomized controlled trial. Brain Behavior, and Immunity 2009;23:184 8.

van Dam D, Ehring T, Vedel E, Emmelkamp PM. Trauma-focused treatment for posttraumatic stress disorder combined with CBT for severe substance use disorder: a randomized controlled trial. BMC Psychiatry 2013;13:172 85.

Dorshkind K, Montecino-Rodriguez E, Signer R a J. The ageing immune system: is it ever too old to become young again? Nature Reviews. Immunology 2009;9:57 62.

Ehlers A, Bisson J, Clark DM, Creamer M, Pilling S, Richards D, et al. Do all psychological treatments really work the same in posttraumatic stress disorder? Clinical Psychology Review 2010;30:269 76.

Epel ES, Blackburn EH, Lin J, Dhabhar FS, Adler NE, Morrow JD, et al. Accelerated telomere shortening in response to life stress. Proceedings of the National Academy of Sciences of the United States of America 2004;101:17312 5.

Ertl V, Pfeiffer A, Schauer E, Elbert T, Neuner F. Community-implemented trauma therapy for former child soldiers in Northern Uganda: a randomized controlled trial. JAMA: The Journal of the American Medical Association 2011;306:503 12.

Fagnoni FF, Vescovini R, Passeri G, Bologna G, Pedrazzoni M, Lavagetto G, et al. Shortage of circulating naive CD8(+) T cells provides new insights on immunodeficiency in aging. Blood 2000;95:2860 8.

Felitti VJ, Anda RF, Nordenberg D, Williamson DF, Spitz AM, Edwards V, Koss MP, Marks JS. Relationship of childhood abuse and household dysfunction to many of the leading causes of death in adults. The Adverse Childhood Experiences (ACE) Study. American Journal of Preventive Medicine 1998;14:245 58.

Hamann D, Roos MTL, van Lier RAW. Faces and phases of human CD8+ T-cell development. Immunology Today 1999;20:177 80.

Hamilton M. A rating scale for depression. Journal of Neurology, Neurosurgery, and Psychiatry 1960;23:56 62.

Hamuni H, Gola H, Sommershof A, Kolassa S, Elbert T, Groettrup M, Kolassa I-T. No reduction of naive and regulatory $\mathrm{T}$ cells following examination stress, submitted for publication.

Hedges LV. Distribution theory for glass's estimator of effect size and related estimators. Journal of Educational and Behavioral Statistics 1981;6:107 28.

Hensel-Dittmann D, Schauer M, Ruf M, Catani C, Odenwald M, Elbert T, et al. Treatment of traumatized victims of war and torture: a randomized controlled comparison of narrative exposure therapy and stress inoculation training. Psychotherapy and Psychosomatics 2011;80:345 52.

Himmerich H, Milenović S, Fulda S, Plümäkers B, Sheldrick AJ, Michel TM, et al. Regulatory $\mathrm{T}$ cells increased while IL-1beta decreased during antidepressant therapy. Journal of Psychiatric Research 2010;44:1052 7.

Hong MS, Dan JM, Choi J-Y, Kang I. Age-associated changes in the frequency of naïve, memory and effector CD8 + T cells. Mechanisms of Ageing and Development 2004;125:615 8.

Hosaka T, Tokuda Y, Sugiyama Y, Hirai K, Okuyama T. Effects of a structured psychiatric intervention on immune function of cancer patients. The Tokai Journal of Experimental and Clinical Medicine 2000;25:183 8.

Ironson G, Wynings C, Schneiderman N, Baum a, Rodriguez M, Greenwood D, et al. Posttraumatic stress symptoms, intrusive thoughts, loss, and immune function after Hurricane Andrew. Psychosomatic Medicine 1997;59:128 41.

Von Känel R, Hepp U, Kraemer B, Traber R, Keel M, Mica L, et al. Evidence for lowgrade systemic proinflammatory activity in patients with posttraumatic stress disorder. Journal of Psychiatric Research 2007;41:744 52.

Kawamura N, Kim Y, Asukai N. Suppression of cellular immunity in men with a past history of posttraumatic stress disorder. The American Journal of Psychiatry 2001;158:484 6

Kiecolt-Glaser JK, Preacher KJ, Maccallum RC, Atkinson C, Malarkey WB, Glaser R. Chronic stress and age-related increases in the proinflammatory cytokine IL-6. PNAS 2003:100:9090 5.

Kleim B, Grey N, Wild J, Nussbeck FW, Stott R, Hackmann A, et al. Cognitive change predicts symptom reduction with cognitive therapy for posttraumatic stress disorder. Journal of Consulting and Clinical Psychology 2012;81:383 93.

Kolassa IT, Ertl V, Eckart C, Kolassa S, Onyut LP, Elbert T. Spontaneous remission from PTSD depends on the number of traumatic event types experienced. Psychological Trauma: Theory, Research, Practice, and Policy 2010;2:169 74.

Laudenslager ML, Aasal R, Adler L, Berger CL, Montgomery PT, Sandberg E, et al. Elevated cytotoxicity in combat veterans with long-term post-traumatic stress disorder: preliminary observations. Brain, Behavior, and Immunity 1998;12:74 9.

Morath J, Moreno-Villanueva M, Hamuni G, Kolassa S, Ruf-Leuschner M, Schauer M, et al. Effects of psychotherapy on DNA strand break accumulation originating from traumatic stress. Psychotherapy and Psychosomatics; 2014 (in press).

Neuner F, Elbert T. The mental health disaster in conflict settings: can scientific research help? BMC Public Health 2007;7:275.

Neuner F, Onyut PL, Ertl V, Odenwald M, Schauer E, Elbert T. Treatment of posttraumatic stress disorder by trained lay counselors in an African refugee settlement: a randomized controlled trial. Journal of Consulting and Clinical Psychology 2008;76:686 94.

Neuner F, Schauer M, Karunakara U, Klaschik C, Robert C, Elbert T Psychological trauma and evidence for enhanced vulnerability for posttraumatic stress disorder through previous trauma among West Nile refugees. BMC Psychiatry 2004a;4:34.

Neuner F, Schauer M, Klaschik C, Karunakara U, Elbert T. A comparison of narrative exposure therapy, supportive counseling, and psychoeducation for treating posttraumatic stress disorder in an African refugee settlement. Journal of Consulting and Clinical Psychology 2004b;72:579 87. 
Pace TWW, Heim CM. A short review on the psychoneuroimmunology of posttraumatic stress disorder: from risk factors to medical comorbidities. Brain Behavior, and Immunity 2011:25:6 13.

Petrie Keith J, Fontanilla I, Thomas MG, Booth RJ, Pennebaker JW. Effect of written emotional expression on immune function in patients with human immunodeficiency virus infection: a randomized trial. Psychosomatic Medicine 2004;66:272 5 .

Rief W, Hiller W. A new approach to the assessment of the treatment effects of somatoform disorders. Psychosomatics 2003;44:492 8 .

Robjant K, Fazel M. The emerging evidence for narrative exposure therapy: a review. Clinical Psychology Review 2010;30:1030 9.

Sallusto F, Lenig D, Förster R, Lipp M, Lanzavecchia A. Two subsets of memory T lymphocytes with distinct homing potentials and effector functions. Nature 1999;401:708 12

Sareen J, Cox BJ, Stein MB, Afifi TO, Fleet C, Asmundson GJG. Physical and menta comorbidity, disability, and suicidal behavior associated with posttraumatic stress disorder in a large community sample. Psychosomatic Medicine 2007;69: 2428.

Schauer M, Neuner F, Elbert T. Narrative exposure therapy: a short-term treatment for traumatic stress disorders. 2nd revised. Cambridge/Göttingen: Hogrefe \& Huber Publishers, 2011a.

Schauer M, Neuner F, Elbert T. Vivo event checklist for war, detention, and torture experiences. Narrative exposure therapy: a short-term treatment for traumatic stress disorders. 2nd revised. Cambridge/Göttingen: Hogrefe \& Huber Publishers; 2011b. pp. 779

Seidler GH, Wagner FE Comparing the efficacy of EMDR and trauma-focused cognitive-behavioral therapy in the treatment of PTSD: a meta-analytic study. Psychological Medicine 2006;36:1515 22.

Sheehan DV, Lecrubier Y, Sheehan KH, Amorim P, Janavs J, Weiller E, et al. The MiniInternational Neuropsychiatric Interview (MINI): the development and validation of a structured diagnostic psychiatric interview for DSM-IV and ICD-10. Journal of Clinical Psychiatry 1998;59:22 33.
Shen SS, Kim JS, Weksler ME. Effect of age on thymic development, T cell immunity, and helper T cell function. Reviews of Physiology, Biochemistry and Pharmacology 1999:139:123 39.

Sherman BF, Bonanno G a, Wiener LS, Battles HB. When children tell their friends they have AIDS: possible consequences for psychological well-being and disease progression. Psychosomatic Medicine 2000;62:238 47.

Sommershof A, Aichinger $\mathrm{H}$, Engler $\mathrm{H}$, Adenauer $\mathrm{H}$, Catani $\mathrm{C}$, Boneberg $\mathrm{E}-\mathrm{M}$, et al. Substantial reduction of naïve and regulatory $\mathrm{T}$ cells following traumatic stress. Brain, Behavior, and Immunity 2009;23:1117 24.

Spitzer C, Barnow S, Völzke H, Wallaschofski H, John U, Freyberger HJ, et al. Association of posttraumatic stress disorder with low-grade elevation of C-reactive protein: evidence from the general population. Journal of Psychiatric Research 2010:44:15 21.

Teicher MH, Anderson CM, Polcari A. Childhood maltreatment is associated with reduced volume in the hippocampal subfields CA3, dentate gyrus, and subiculum. Proceedings of the National Academy of Sciences of the United States of America 2012;109:563 72

Vidović A, Vilibić M, Sabioncello A, Gotovac K, Rabatić S, Folnegović-Smalc V, et al. Circulating lymphocyte subsets, natural killer cell cytotoxicity, and components of hypothalamic-pituitary-adrenal axis in Croatian war veterans with posttraumatic stress disorder: cross-sectional study. Croatian Medical Journal 2007;48:198 206.

Vignali DAA, Collison LW, Workman CJ. How regulatory T cells work. Nature Review Immunology 2008;8:523 32

Weisberg RB, Bruce SE, Machan JT, Kessler RC, Culpepper L, Keller MB. Nonpsychiatric illness among primary care patients with trauma histories and posttraumatic stress disorder. Psychiatric Services 2002;53:848 54.

Wildin R, Smyk-Pearson S, Filipovich A. Clinical and molecular features of the immunodysregulation, polyendocrinopathy, enteropathy, X linked (IPEX) syndrome. Journal of Medical Genetics 2002;39:537 45.

Wilson SN, van der Kolk B, Burbridge J, Fisler R, Kradin R. Phenotype of blood lymphocytes in PTSD suggests chronic immune activation. Psychosomatics 1999;40:222 5 . 